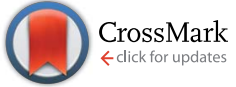

Cite this: RSC Adv., 2014, 4, 32249

Received 7th May 2014

Accepted 3rd July 2014

DOI: $10.1039 / c 4 r a 04250 f$

www.rsc.org/advances

\title{
Reusable bacteria immobilized electrospun nanofibrous webs for decolorization of methylene blue dye in wastewater treatment
}

\author{
Nalan Oya San, ${ }^{* a b}$ Aslı Celebioglu, ${ }^{\text {cd }}$ Yasin Tümtaş, ${ }^{\text {cd }}$ Tamer Uyar $^{* c d}$ \\ and Turgay Tekinay*be
}

In our study, an electrospun cellulose acetate nanofibrous web (CA-NFW) was found to be quite effective in immobilizing bacterial cells. Here, decolorization of methylene blue (MB) dye in aqueous medium was achieved by using three types of bacteria (Aeromonas eucrenophila, Clavibacter michiganensis and Pseudomonas aeruginosa) immobilized on the CA-NFW. The decolorization time $(0-48 \mathrm{~h})$ and different $\mathrm{MB}$ dye concentrations (20-500 $\mathrm{mg} \mathrm{L}^{-1}$ ) were studied to elucidate the maximum MB dye removal by the bacteria immobilized CA-NFWs. The effective dye decolorization was achieved within 24 hours and MB dye removal was $\sim 95 \%$. Interestingly, MB dye decolorization performance of bacteria immobilized CA-NFWs was quite close to that of free bacteria. We have also tested the reusability of bacteria immobilized NFWs after four cycles and $\sim 45 \%$ of the dye decolorization capacity was obtained at the end of the 4th cycle. These results are quite promising and therefore suggest that bacteria immobilized electrospun NFWs could be quite applicable for the decolorization of dyes in wastewater due to their versatility and reusability.

\section{Introduction}

Discharge from industrial plants usually consists of many unwanted effluents, and part of it is comprised of dyes. Synthetic dyes are widely used in textile, leather, paper, pulp, plastic and printing industries. At the moment, approximately 8000 chemical problems are known to be associated with the dyeing process. Annually, 700000 tons of dye related products are fabricated in the world..$^{1-4}$ Apart from the esthetic view point, most of the dyes contain carcinogens such as; benzidine which requires treatment before it is drained into the environment. Furthermore, untreated water reduces solubility of the gas in water resources..$^{5-7}$ Methylene blue (MB) is one of the common dyes used in the textile industry. ${ }^{8}$ Yet, the efficient and costeffective treatment of $\mathrm{MB}$ from aqueous systems remains a challenge. A range of conventional techniques have been

${ }^{a}$ Polatl Science and Literature Faculty, Biology Department, Gazi University, Ankara 06900, Turkey. E-mail: oyasan@gazi.edu.tr; Fax: +90 (312) 266 4365; Tel: +90 (312) 2903571

${ }^{b}$ Life Sciences Application and Research Center, Gazi University, Ankara 06830, Turkey 'Institute of Materials Science and Nanotechnology, Bilkent University, 06800 Ankara, Turkey. E-mail: tamer@unam.bilkent.edu.tr; Fax: +90 (312) 484 6271; Tel: +90 (312) 4846270

${ }^{d}$ UNAM-National Nanotechnology Research Center, Bilkent University, Ankara 06800, Turkey

${ }^{e}$ Faculty of Medicine, Department of Medical Biology and Genetics, Gazi University, Ankara 06560, Turkey. E-mail: ttekinay@gazi.edu.tr; Fax: +90 (312) 266 4365; Tel: +90 (312) 2903571 extensively investigated, such as activated sludge, ${ }^{9}$ carbon adsorption, ${ }^{\mathbf{1 0}}$ chemical coagulation, ${ }^{11}$ reverse osmosis, ${ }^{12}$ electrochemical treatment, ${ }^{13}$ hydrogen peroxide catalysis ${ }^{\mathbf{1 4}}$ and photocatalysis. ${ }^{\mathbf{1 5 , 1 6}}$ Although some of the techniques are proven to be effective, none of them were successful in complete removal of dyes. Furthermore, each of them has their own limitations. Recent research has focused on the development of cost-effective, renewable, eco-friendly, locally available and efficient alternatives, such as microorganisms, which are capable of biodegrading and biosorbing the dyes in wastewater. Notably, they are bacteria, fungi and algae, and can decolorize a wide range of dyes with high efficiency. ${ }^{17-20}$ On the other hand, when compared to algae and fungi, bacteria are easier to culture, grow faster and are able to accumulate contaminants under a broad range of external conditions. ${ }^{21}$

MB is a basic, thiazine cationic dye which has widespread applications in coloring paper, temporary hair colorant, dyeing cottons, wools and coating for paper stock. It is also used in microbiology, surgery and diagnostics and as a sensitizer in photo-oxidation of organic pollutants. ${ }^{22-27}$

Electrospinning has recently emerged as a promising technique for the production of nanofiber/nanoweb due to its simplicity, versatility and cost-effectiveness. ${ }^{28}$ Electrospun nanofibrous webs (NFW) exhibit unique properties including very large surface area to volume ratio along with nanoscale porosity which makes them promising as filter and membrane materials for environmental applications. ${ }^{28-31}$ The integration of electrospun nanofibers with microorganism can enhance the 
potential of these NFW for the filtration and purification purposes. Balamurugan et al. ${ }^{32}$ summarized the trends in NF membranes and their suitability for air and water filtration. Especially the potential applications are in textile industry, air cleaning in hospitals and other domains.

Yet, there are very few studies in the literature on the incorporation of microorganisms in electrospun nanofibers. ${ }^{33-39}$ The results from these studies suggest that, the functional nanofibers containing bacteria or algae have great potential for the environmental practices. For instance, in a study by Klein et $a .^{35}$ Pseudomonas sp. ADP was encapsulated in the core part of core-shell nanofibers for the degradation of atrazine which is a widely used herbicide. In another study of Eroglu et al. ${ }^{33}$ algal cells were effectively immobilized on electrospun chitosan nanofiber mats to generate a hybrid system for nitrate removal. Moreover, one of the related study was performed by our group in which Acinetobacter calcoaceticus STB1 cells were immobilized on electrospun cellulose acetate nanofibrous webs (CA-NFW) in order to achieve enhanced ammonium removal in aqueous environments. ${ }^{38}$ In this study, it was shown that, STB1/ CA-NFW can be reused without significant loss of their ammonium removal capacity. It is notable that bacteria is employed in treating wastewater, ${ }^{\mathbf{4 0 - 4 2}}$ there are no reports in the context when such bacteria were immobilized on electrospun NFW for the decolorization of dyes. Hence, in this study we comparatively investigated three bacteria for their decolorization efficiency, namely Aeromonas eucrenophila, Clavibacter michiganensis and Pseudomonas aeruginosa immobilized on CA-NFW. This immobilization is quite advantageous when compared to free cells in suspension. For instance, the integration of bacteria with the NFW allows us for ease of handling, reusabililty and doesn't require a separate growth medium. Additionally, the surface attachment of microorganisms onto nanofibers is advantageous which can lead to higher cell sustainability and activity. Moreover, microbial biofilm formation can be supported by nanofiber structures, and as a result the whole system provides a stable and accelerated biodecolorization/degradation.

At present, there is no single process which is capable of treating wastewater. In the light of literature, it will be smart to combine different techniques such as nanofiber and bacteria to be employed in wastewater treatment. Therefore, in our study, the above mentioned bacteria were individually immobilized onto electrospun porous CA-NFW which were then used for the treatment of aqueous medium containing MB. The results suggested that, electrospun CA-NFW were very effective to immobilize bacteria. To maximize the removal capacity of dye through bacteria immobilized NFW, we have studied decolorization time and different dye concentrations. Finally, the reusability of bacteria immobilized CA-NFW was tested.

\section{Experimental}

\section{Electrospinning of cellulose acetate nanofibrous webs (CA-NFW)}

The electrospinning of porous CA-NFW was performed as detailed in our previous studies. ${ }^{38,43}$ The chemicals were purchased from Sigma-Aldrich (Germany) and used without any purification (dichloromethane, DCM, $\geq 99 \%$ (GC); acetone, $\geq 99 \%$ (GC); cellulose acetate, (CA, $M_{\mathrm{w}}: 30000 \mathrm{~g} \mathrm{~mol} \mathrm{~m}^{-1}$, $39.8 \mathrm{wt} \%$ acetyl)). A clear electrospinning solution was prepared by dissolving CA in a DCM/acetone $(2 / 1(\mathrm{v} / \mathrm{v}))$ binary solvent mixture at $7.5 \%(\mathrm{w} / \mathrm{v})$ polymer concentration. Then, this solution was taken in a $3 \mathrm{~mL}$ syringe fitted with a metallic needle of $0.6 \mathrm{~mm}$ inner diameter. The syringe was located horizontally on a syringe pump (model KDS-101, KD Scientific, USA). The electrode of the high-voltage power supply (Spellman, SL30, USA) was clamped to the metallic needle, and the plate aluminum collector was grounded. Electrospinning parameters were arranged as follows: feed rate of solutions $=1 \mathrm{~mL} \mathrm{~h}^{-1}$, applied voltage $=15 \mathrm{kV}$, tip-to-collector distance $=10 \mathrm{~cm}$. Electrospun CA-NFW were deposited on a grounded stationary metal collector covered with an aluminum foil. The electrospinning apparatus was enclosed in a Plexiglas box and electrospinning was carried out at $25{ }^{\circ} \mathrm{C}$ at $20 \%$ relative humidity. The collected nanofibers/nanowebs were dried over night at room temperature in a fume hood.

\section{Bacterial strain}

This study was performed using pure cultures of the Aeromonas eucrenophila (GenBank ID: GQ466170) and Clavibacter michiganensis (GenBank ID: GQ466171) which are isolated from water samples taken from water treatment system. While, Pseudomonas aeruginosa (ATCC 47085) is taken from Culture Collection of Gazi University, Life Sciences Application and Research Center. A. eucrenophila is a Gram-negative, rod-shaped, mainly motile, facultative anaerobic, oxidase positive and glucose-fermenting bacterium. ${ }^{44}$ C. michiganensis is a Gram positive, rodshaped and aerobic bacterium. ${ }^{45,46} P$. aeruginosa is a Gramnegative, aerobic, coccobacillus bacterium with unipolar motility. ${ }^{47}$ Pure cultures were kept at $4{ }^{\circ} \mathrm{C}$ and transferred them to N. Agar medium every 3 months.

\section{Contaminant: methylene blue (MB)}

$\mathrm{MB}\left(\mathrm{C}_{16} \mathrm{H}_{18} \mathrm{~N}_{3} \mathrm{ClS}\right.$, CAS no. 61-73-4) was purchased from SigmaAldrich (Germany). The stock solution of $\mathrm{MB}$ was prepared (200 $\mathrm{mg} \mathrm{L}^{-1}$ ) in distilled water. The concentration of MB in each aqueous solution was measured on an UV-vis spectrophotometer while taking the absorption at $660 \mathrm{~nm}$.

\section{Growth and immobilization of bacterial strain}

Nutrient Broth (peptone from meat $5.0 \mathrm{~g}$, meat extract $3.0 \mathrm{~g}$ and sodium chloride $6.0 \mathrm{~g}$ in $1 \mathrm{~L}$ ) medium ( $\mathrm{pH} 7$ ) for immobilization experiments was sterilized and inoculated with $1 \mathrm{~mL}\left(\sim 10^{7} \mathrm{CFU}\right.$ $\mathrm{mL}^{-1}$ ) of bacterial culture. $20 \mathrm{mg}$ of sterilized CA-NFW were added to the inoculation flasks and incubated at $30{ }^{\circ} \mathrm{C}$ in a rotary shaker at $100 \mathrm{rpm}$ for 7 days.

\section{Morphological characterization of NFW, bacteria and bacteria immobilized CA-NFW}

The morphologies of pristine CA-NFW, bacteria (Aeromonas eucrenophila, Clavibacter michiganensis and Pseudomonas 
aeruginosa), and bacteria immobilized CA-NFW were investigated by using Scanning Electron Microscope (SEM, Quanta 200 FEG, FEI Instruments, USA). Samples were washed twice with PBS buffer and fixed by overnight incubation in $2.5 \%$ glutaraldehyde at room temperature. Then the samples were dehydrated by immersing in a series of ethanol-water solutions ranging from $20 \%$ to $100 \%$. Prior to SEM imaging, all samples were coated with a $5 \mathrm{~nm}$ layer of gold-palladium.

\section{MB decolorization test: effect of contact time}

$20 \mathrm{mg}$ of NFW were dropped into $50 \mathrm{~mL}$ dye solution $(20 \mathrm{mg}$ $\mathrm{L}^{-1}$ ) and placed on a constant temperature shaking incubator at $30{ }^{\circ} \mathrm{C}$ for different time (3, 12, 24 and 48 hours). The same dye concentration $\left(20 \mathrm{mg} \mathrm{L}^{-1}\right)$ is employed to obtain positive control with bacterial inoculum, negative control with CA NFW and experimental set with bacteria immobilized CA-NFW.

\section{MB decolorization test: effect of initial dye concentration}

Textile processing wastewater with dye contents in the range of $10-200 \mathrm{mg} \mathrm{L}^{-1}$ are highly colored. ${ }^{48}$ For this reason, initial dye concentrations were adjusted to $20,100,250$, and $500 \mathrm{mg} \mathrm{L}^{-1}$ to represent low, medium and high concentrations of dye. $20 \mathrm{mg}$ of NFW and $50 \mathrm{~mL}$ different concentrations of MB dye solutions $\left(20,100,250\right.$, and $\left.500 \mathrm{mg} \mathrm{L}^{-1}\right)$ were put into a $100 \mathrm{~mL}$ conical flask. Then the conical flasks were placed on a constant temperature shaking incubator at $30{ }^{\circ} \mathrm{C}$. A $5 \mathrm{~mL}$ sample was taken daily from each flask. Samples were centrifuged to precipitate suspended biomass at $3421 \times g$ for $10 \mathrm{~min}$. Supernatant was analyzed by the UV-vis spectrophotometer to measure the residual concentration of MB. The results are given as reduced dye concentrations. The removal yield is defined as the ratio of reduced concentration of dye to the initial dye concentrations. Removal percentage is calculated from eqn (1)

$$
R \%=\frac{C_{0}-C_{\mathrm{eq}}}{C_{0}} \times 100
$$

where $C_{0}$ and $C_{\text {eq }}$ are the initial and equilibrium concentrations of $\mathrm{MB}\left(\mathrm{mg} \mathrm{L}^{-1}\right)$, respectively. Each experiment was carried out in triplicate. All determinations were made daily during the incubation period.

\section{Reusability experiments for bacteria immobilized CA-NFW}

MB decolorization studies were performed 4 times to assess the reusability of the bacteria immobilized NFW for an initial concentration of $20 \mathrm{mg} \mathrm{L}^{-1}$. Before each cycle, NFW pieces were washed three times with sterile PBS buffer and incubated overnight in PBS to remove any unattached bacteria. MB decolorization experiments were performed at $100 \mathrm{rpm}$ and $30{ }^{\circ} \mathrm{C}$ for $48 \mathrm{~h}$ after each washing step, for a total of 4 cycles. Dye concentrations were measured at $0 \mathrm{~h}$ and $48 \mathrm{~h}$. Each cycle was terminated after $48 \mathrm{~h}$ of total incubation and washing steps were repeated for NFW samples before the initiation of the next cycle. All tests were done in triplicate.

\section{Results and discussion}

\section{Immobilization of $A$. eucrenophila, $C$. michiganensis and $P$. aeruginosa on CA-NFW}

Schematic representation of the electrospinning process for CA nanofibers, attachment of bacterial cells on CA-NFW and photograph of the decolorization test are shown in Fig. 1. Fig. 2 shows the representative SEM images of porous CA-NFW. Generally, electrospun CA nanofibers have smooth fiber morphology. ${ }^{43}$ However, we can produce porous CA nanofibers by employing highly volatile solvent mixture (DCM/acetone) as reported in our previous study. ${ }^{43} \mathrm{CA}-\mathrm{NFW}$ is an effective support and has an advantage for facilitating the diffusion of vital nutrients and waste products between the environment and the bacteria. In addition, these webs are biodegradable and biocompatible, which can be rendered for biological applications $^{49}$ so CA is quite applicable and favorable especially for the wastewater treatment purposes.

Representative SEM images (after $24 \mathrm{~h}$ of incubation) are shown in Fig. 3a-c for A. eucrenophila, C. michiganensis and $P$. aeruginosa cells, respectively. As seen in Fig. 3, A. eucrenophila and $C$. michiganensis are rod shape, and $P$. aeruginosa has coccobasil morphology. SEM analysis was performed after 7 days of incubation for the bacterial attachment to NFW and shown in Fig. 4a-c. As seen in the Fig. 4, after 7 days, three types of bacteria were attached and formed biofilm layers on the NFW. Biofilms are communities of microorganisms in a matrix that joins them together and to living or inert substrates. ${ }^{50}$ In the light of literature, we know that $P$. aeruginosa has been extensively utilized as a model organism for the biofilm experiments. ${ }^{51}$ Moreover, San et al. ${ }^{52,53}$ showed that $A$. eucrenophila and $C$. michiganensis produced compact biofilm and caused microbial corrosion.

\section{Decolorization assay}

The effects of experimental parameters such as contact time $(0-48 \mathrm{~h})$ and initial dye concentration $\left(20-500 \mathrm{mg} \mathrm{L}^{-1}\right)$ on the decolorization of MB were studied. The decolorization of dyes by bacteria could be due to adsorption by microbial cells or biodegradation. Dye adsorption can be clearly judged by inspecting the cell mats. Cell mats become deeply colored because of the adsorbed dyes, whereas those retain their original color when biodegradation takes place. ${ }^{54}$ In our study, we observed that bacteria decolorized the MB by degradation. In addition, no decolorization activity was detected in the supernatant of culture media after the removal of cells. This implies that no secreted enzyme or any other bioproduct might be involved in decolorization.

Contact time is one of the important parameters to successfully adsorb the pollutants for practical application. To ensure that adequate time was given for the decolorization of $\mathrm{MB}$, the optimum decolorization time of $\mathrm{MB}$ by bacteria immobilized CA-NFW was determined. Free bacteria and pristine CA-NFW were also tested for comparison. The MB decolorization performance of bacteria-free CA-NFW, free bacteria and bacteria immobilized CA-NFW after certain time periods ( 3 h, 12 h, 24 h and 48 h) are shown in Fig. 5. As seen in Fig. 5, 


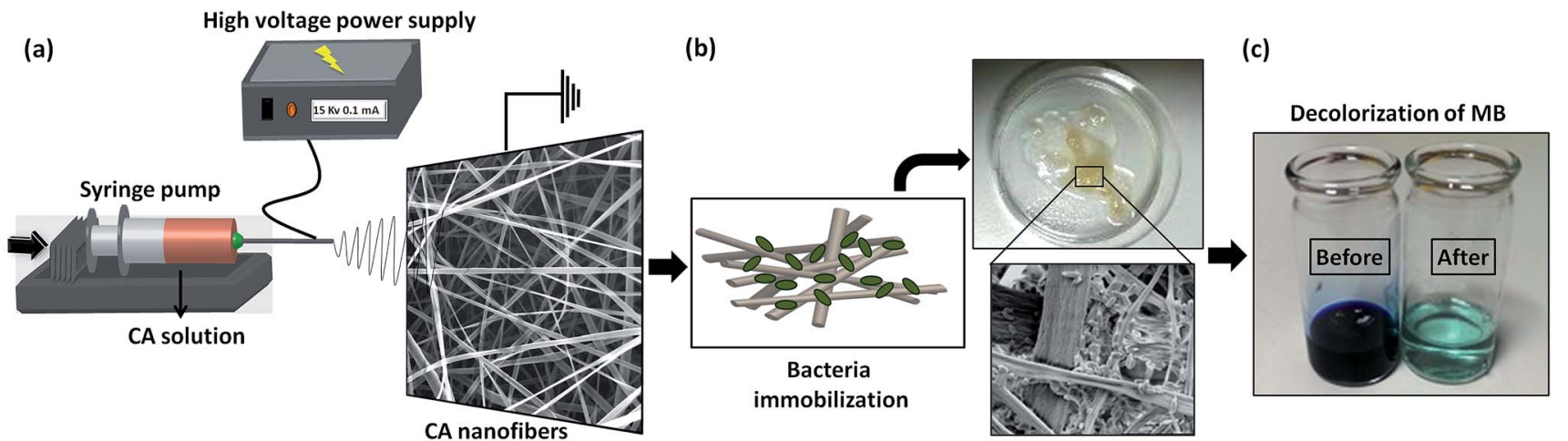

Fig. 1 Schematic representation of the electrospinning process for CA nanofibers, immobilization of bacterial cells on CA nanofibrous web and photograph of the decolarization process.
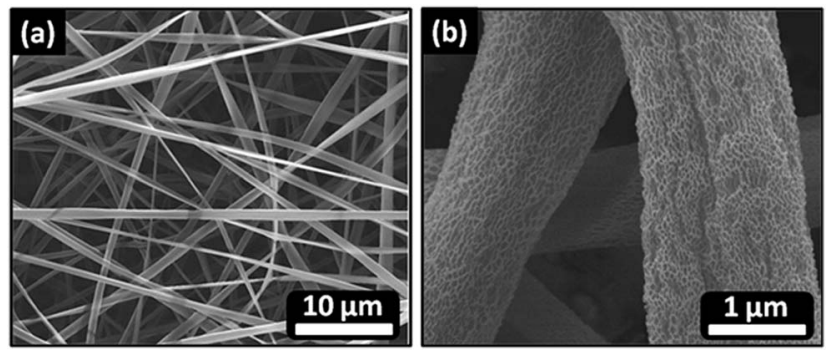

Fig. 2 Representative SEM images of electrospun CA nanofibrous web (a) low magnification, and (b) high magnification.
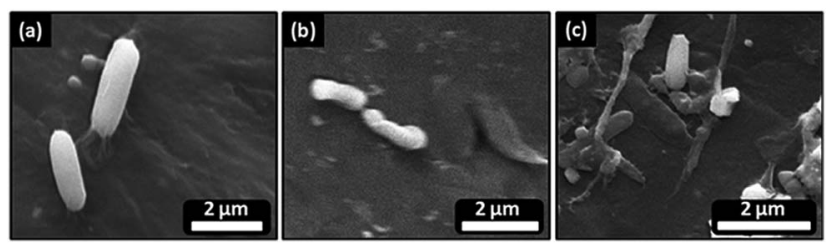

Fig. 3 General morphology of (a) Aeromonas eucrenophila (b) Clavibacter michiganenesis (c) Pseudomonas aeruginosa by SEM.

bacteria-free CA-NFW was responsible for the initial removal of MB dye by adsorption from the aqueous environment due to its very high surface area. The maximum removal of MB was around $15 \%$ after $48 \mathrm{~h}$. On the other hand, the MB decolorization by free bacteria and bacteria immobilized CA-NFW was increased dramatically in the first $24 \mathrm{~h}$ in which the MB removal was around $95 \%$ and a very slight improvement was observed after $48 \mathrm{~h}$. The highest \% removal of MB dye was obtained after $48 \mathrm{~h}$, therefore, $48 \mathrm{~h}$ time period was selected as a suitable contact time for all the other decolorization tests we have performed. After $48 \mathrm{~h}$, \% removal of MB dye was calculated as 15.8 $\pm 1.3 \%$ for bacteria-free CA-NFW. Yet, much efficient $\mathrm{MB}$ removal was achieved by bacteria immobilized CA-NFW; $96.5 \pm$ $0.4 \%, 96.1 \pm 0.4 \%$ and $95.6 \pm 0.3 \%$ for $P$. aeruginosa, $A$. eucrenophila and $C$. michiganensis immobilized CA-NFW, respectively. Likewise, in the case of free bacteria, P. aeruginosa (97.3 \pm 1.4) had slightly better decolorization performance than
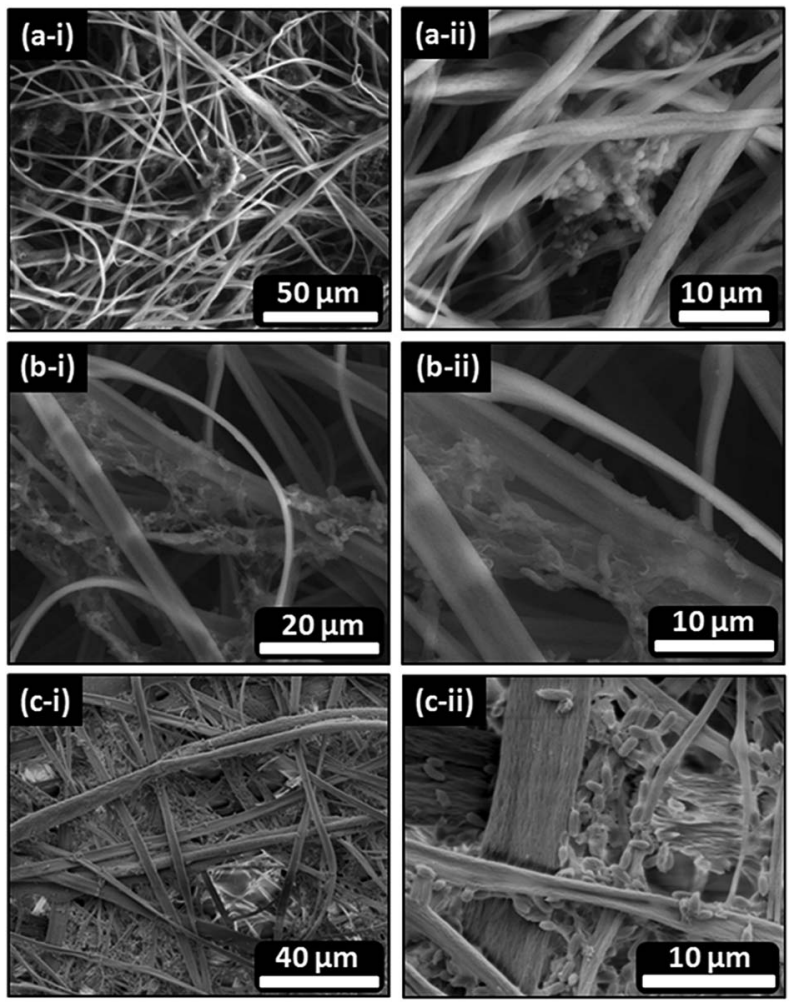

Fig. 4 Representative SEM images of CA nanofibrous web after immobilization of (a-i and a-ii) Aeromonas eucrenophila, (b-i and b-ii) Clavibacter michiganenesis, (c-i and c-ii) Pseudomonas aeruginosa after 7 days.

A. eucrenophila $(95.6 \pm 1.2)$ and C. michiganensis $(97.1 \pm 2.4)$ (Fig. 5). Slightly higher efficiency of $P$. aeruginosa might be originated from rapid growth and dye resistance properties of Pseudomonas which is widely used for decolorization of textile dyestuff in industry wastewater. ${ }^{55-58}$

Our results showed that decolorization performance of bacteria immobilized CA-NFW are very impressive and quite close to the free bacteria, nevertheless, using bacteria immobilized CA-NFW has certain advantages than using free bacteria. Firstly, bacteria immobilized NFW can be reusable whereas free 

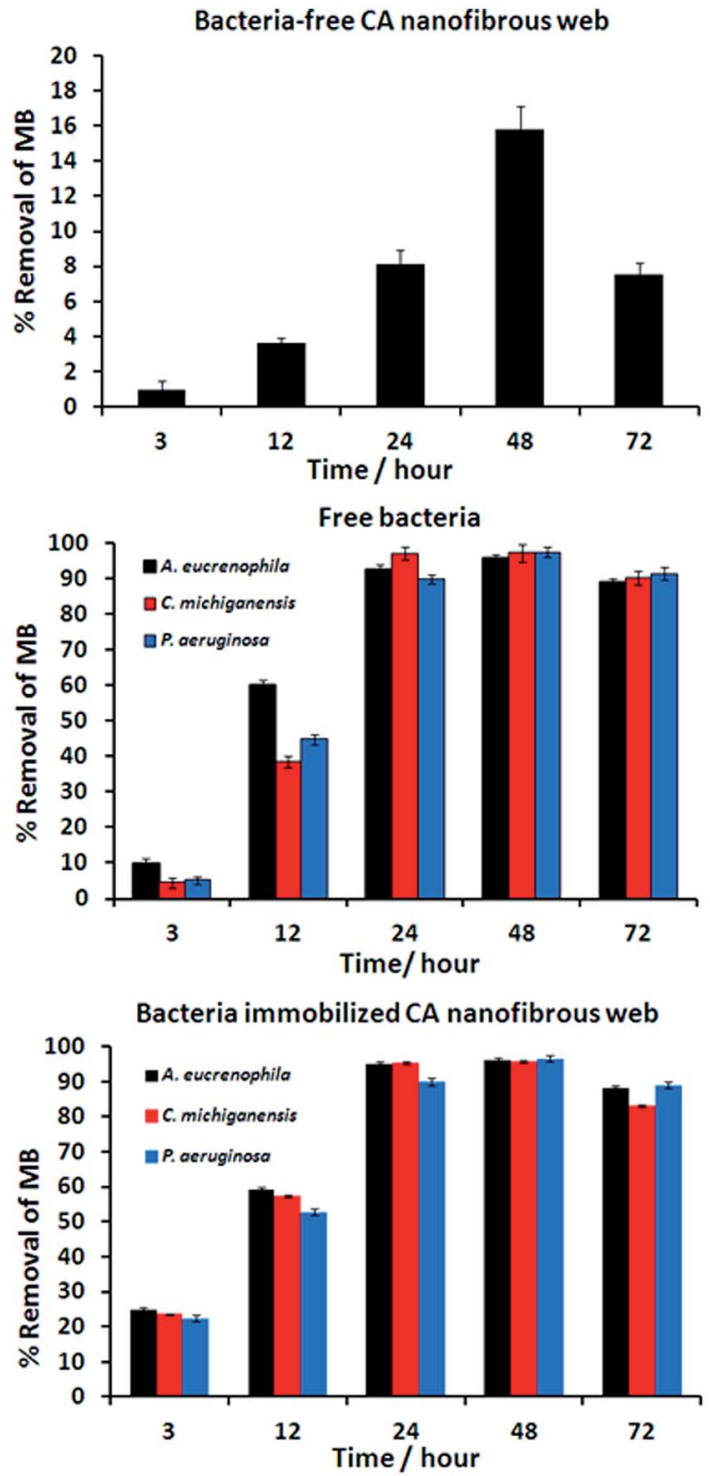

Fig. 5 The effect of contact time on the decolorization yield of the bacteria immobilized CA nanofibrous web in the $20 \mathrm{mg} \mathrm{L}^{-1} \mathrm{MB}(\mathrm{pH} 7$; $T$ : $30{ }^{\circ} \mathrm{C}$; stirring rate: $100 \mathrm{rpm}$ ). Error bars represent the means of three independent replicates.

bacteria cells when dispersed throughout the medium/wastewater, it is quite difficult to harvest and reuse them in another dye-contaminated wastewater. Secondly, bacteria immobilized NFW occupy less space and require smaller volume of growth medium when compared to stock solutions of free bacteria. So, bacteria immobilized NFW are more practical and cost-effective. Finally, biofilm formation in bacteria immobilized NFW bring some advantages such as higher resistance to harsh environmental conditions such as salinity and metal toxicity.

Bacteria immobilized CA-NFW have shown efficient decolorization of $\mathrm{MB}$ dye within $48 \mathrm{~h}$. In addition, effect of dye concentration on decolorization using A. eucrenophila, C. michiganensis and $P$. aeruginosa immobilized CA-NFW were investigated at different initial dye concentrations between $20 \mathrm{mg} \mathrm{L}^{-1}$ and $500 \mathrm{mg} \mathrm{L}^{-1}$ at $\mathrm{pH} 7$ and the results are shown in Fig. 6.
At the end of the $48 \mathrm{~h}$ incubation period, the maximum \% removal for $20 \mathrm{mg} \mathrm{L}^{-1} \mathrm{MB}$ solution was $96.1 \pm 0.4 \%$, $95.6 \pm$ $0.3 \%$ and $96.5 \pm 0.4 \%$ for A. eucrenophila, C. michiganensis and $P$. aeruginosa immobilized CA-NFW, respectively. However, the $\%$ decolorization capacity decreased with an increase in the dye concentration as expected. For $100 \mathrm{ppm}$ dye concentration, the decolorization capacity of MB by A. eucrenophila, C. michiganensis and $P$. aeruginosa immobilized CA-NFW were $69.9 \pm 1.8$ $\mathrm{mg} \mathrm{L}^{-1}, 65.9 \pm 1.6 \mathrm{mg} \mathrm{L}^{-1}$ and $61.9 \pm 1.3 \mathrm{mg} \mathrm{L}^{-1}$, respectively. When dye concentration is increased to $250 \mathrm{ppm}$, the decolorization capacity was $124 \pm 1.2 \mathrm{mg} \mathrm{L}^{-1}, 120.5 \pm 1.4 \mathrm{mg} \mathrm{L}^{-1}$ and $108.6 \pm 1.4 \mathrm{mg} \mathrm{L}^{-1}$ for A. eucrenophila, C. michiganensis and $P$. aeruginosa immobilized CA-NFW, respectively. In the case of $500 \mathrm{ppm} \mathrm{MB}$ concentration, the removal of MB dye was $115.3 \pm$ $0.4 \mathrm{mg} \mathrm{L}^{-1}, 96.1 \pm 0.4 \mathrm{mg} \mathrm{L}^{-1}$ and $95.6 \pm 0.3 \mathrm{mg} \mathrm{L}^{-1}$ for $A$. eucrenophila, C. michiganensis and P. aeruginosa immobilized CA-NFW, respectively. It was noted that more or less $100 \mathrm{mg} \mathrm{L}^{-1}$ dye was removed by all three bacteria from the solutions having dye concentrations of 100,250 and $500 \mathrm{mg} \mathrm{L}^{-1}$. It is anticipated that the dye removal capacity is relevant to amount of bacteria and nanofiber. Hence, decolorization can be improved with the increase of bacteria and nanofiber quantity.

\section{Reusability results}

Dye decolorization capabilities of reused bacteria immobilized CA-NFW were tested for four cycles of reuse (Fig. 7). It was observed that the MB decolorization efficiency was decreased for higher cycles. The decline in the removal efficiency might be due to detachment of the immobilized bacteria in the washing step. After the three cycles of regeneration, favorable \% removal of $\mathrm{MB}$ dye was observed as $58.3 \%, 50.1 \%$ and $58.6 \%$ for A. eucrenophila, C. michiganensis and P. aeruginosa immobilized CA-NFW, respectively. For the 4th regeneration cycle, the MB decolorization dropped to $45.7 \%, 43.1 \%$ and $48.04 \%$ for A. eucrenophila, C. michiganensis and $P$. aeruginosa immobilized CA-NFW, respectively. For practical applications, the level of reusability is an important issue. $\sim 45 \%$ of the dye decolorization capacity was obtained for the final cycle (4th cycle) which suggests that A. eucrenophila, C. michiganensis and P. aeruginosa

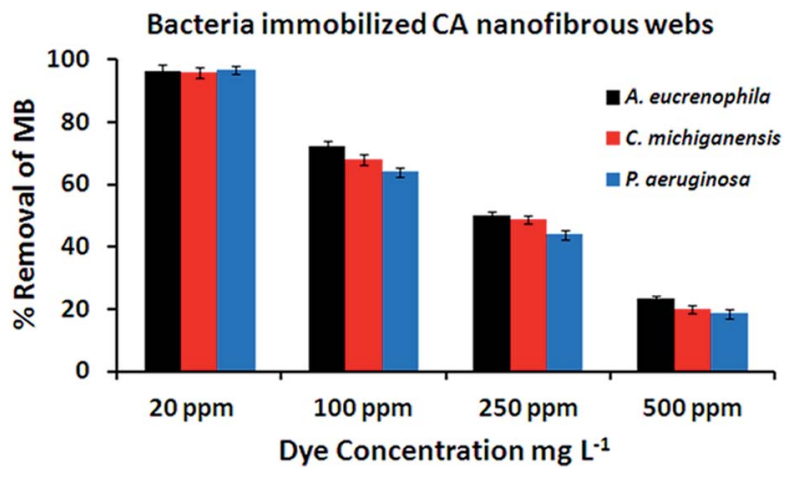

Fig. 6 The effect of initial dye concentration on the decolorization yield of the bacteria immobilized CA nanofibrous web during the $48 \mathrm{~h}$ incubation period ( $\mathrm{pH} \mathrm{7;} \mathrm{T:} 30{ }^{\circ} \mathrm{C}$; stirring rate: $\left.100 \mathrm{rpm}\right)$. Error bars represent the means of three independent replicates. 


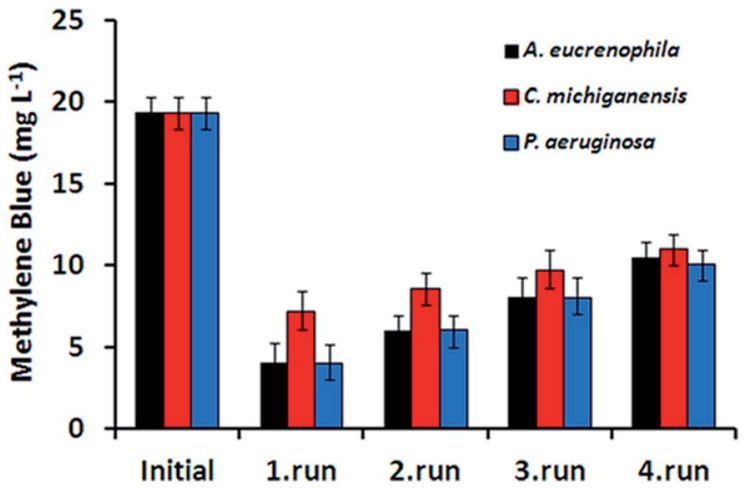

Fig. 7 Reusability test results of the 4 cycles of MB dye decolorization experiments at the initial dye concentration of $20 \mathrm{mg} \mathrm{L}^{-1}$. Error bars represent the means of three independent replicates.

immobilized CA-NFW can sustain their decolorization capacity under several cycles of reuse and may be utilized repeatedly for dye decolorization of wastewater in textile and paint industry. After completion of four cycles for reusability test, the morphology of the used bacteria immobilized CA-NFW was studied by SEM, and the images (Fig. 8) confirmed that the fibrous morphology and bacteria was retained.
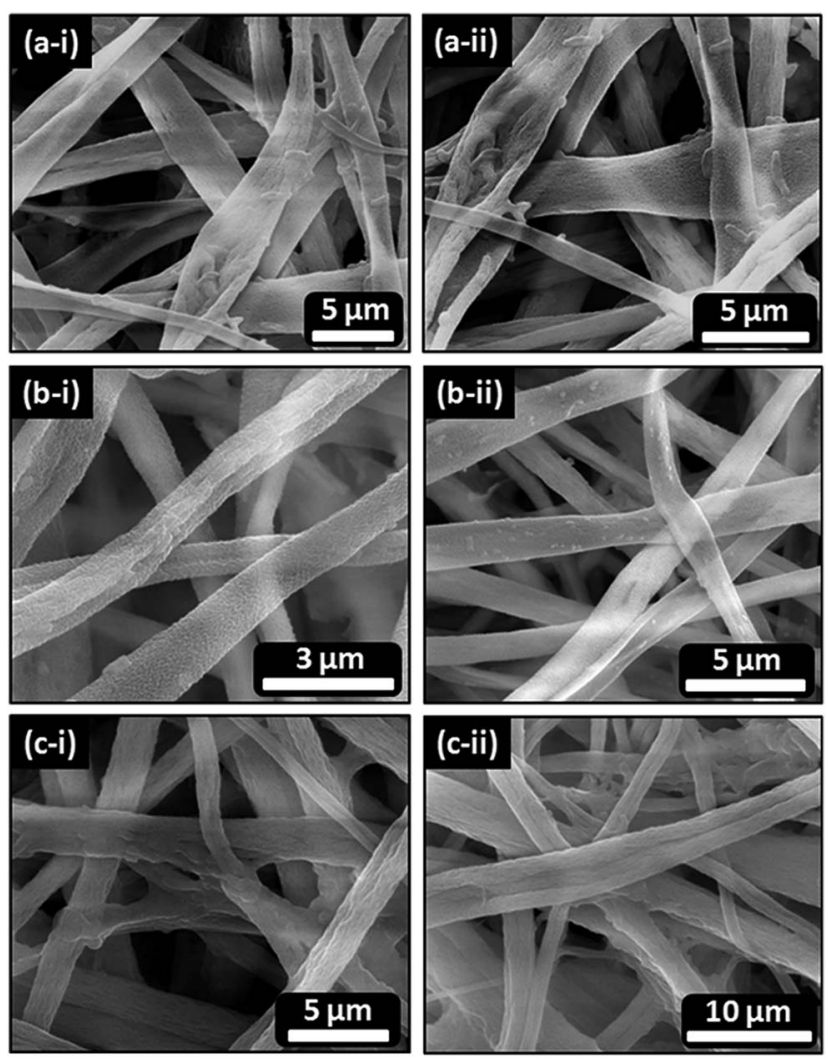

Fig. 8 Representative SEM micrographs of the (a-i and a-ii) A. eucrenophila, (b-i and b-ii) C. michiganensis and (c-i and $c-i i)$ $P$. aeruginosa immobilized CA web after the reusability tests, showing attachment of bacterial biofilms on fiber surfaces.

\section{Conclusions}

We have chosen electrospun CA-NFW as water-insoluble, nontoxic, and highly porous support for immobilization of three types of bacteria which are capable of dye decolorization in wastewater. MB dye was chosen as the target contaminant since it is extensively used in textile and paint industry. The bacteria immobilized CA-NFW were quite successful for the removal of MB dye from the aqueous environment. Due to its simple, reusable and porous characteristics, this NF bio-composite can be a promising membrane material for industrial wastewater treatment. Moreover, this process can be considered harmless for aquatic life during the dye decolorization process.

To the best of our knowledge, our work presents the first detailed study on dye decolorization by bacteria immobilized electrospun NFW. Here, electrospun CA-NFW was found very effective porous solid support for immobilizing bacterial cells. We have immobilized three types of bacteria (A. eucrenophila, $C$. michiganensis and $P$. aeruginosa) on CA-NFW which are capable of decolorization of MB dye solution by degradation. The efficient dye decolorization was achieved within 24 hours and \% removal was about $95 \%$. The reusability of bacteria immobilized NFW was determined after four cycles and $\sim 45 \%$ of the dye decolorization capacity was obtained at the end of the 4 th cycle suggesting that these bacteria immobilized CA-NFW can be reused and may be utilized repeatedly for dye decolorization in industrial wastewater. Our results showed that $\mathrm{MB}$ dye decolorization performance of bacteria immobilized CANFW was quite close to the free bacteria. In short, our findings may be useful for designing and developing an efficient and cost-effective treatment process for the decolorization of dye from industrial wastewater by using bacteria immobilized NFW.

\section{Acknowledgements}

Dr Uyar acknowledges EU FP7-PEOPLE-2009-RG Marie CurieIRG (NANOWEB, PIRG06-GA-2009-256428) and The Turkish Academy of Sciences - Outstanding Young Scientists Award Program (TUBA-GEBIP) for partial funding of the research. A. Celebioglu acknowledges TUBITAK-BIDEB for the national Ph.D. study scholarship. We thank to Dr Sesha Vempati for revising and improving the English of article.

\section{Notes and references}

1 M. Arami, N. Y. Limaee, N. M. Mahmoodi and N. S. Tabrizi, J. Hazard. Mater., 2006, 135, 171-179.

2 J. C. Bellot and J. S. Condoret, Process Biochem., 1993, 28, 365-376.

3 L. Brinza, C. A. Nygard, M. J. Dring, M. Gavrilescu and L. G. Benning, Bioresour. Technol., 2009, 100, 1727-1733.

4 N. Tekin, O. Demirbas and M. Alkan, Microporous Mesoporous Mater., 2005, 85, 340-350.

5 G. F. Liu, J. T. Zhou, J. Wang, Z. Y. Song and Y. Y. Qv, World J. Microbiol. Biotechnol., 2006, 22, 1069-1074.

6 A. Salima, B. Benaouda, B. Noureddine and L. Duclaux, Water Res., 2013, 47(10), 3375-3388. 
7 H. Utomo and K. A. Hunter, Bioresour. Technol., 2010, 101, 1482-1486.

8 M. Bielska and J. Szymanowski, Water Res., 2006, 40, 10271033.

9 W. H. Li, Q. Y. Yue, B. Y. Gao, Z. H. Ma, Y. J. Li and H. X. Zhao, Chem. Eng. J., 2011, 171(15), 320-327.

10 I. A. Aguayo-Villarreal, V. Hernández-Montoya, A. BonillaPetriciolet, R. Tovar-Gómez, E. M. Ramírez-López and M. A. Montes-Morán, Dyes Pigm., 2013, 96(2), 459-466.

11 B. Merzouk, B. Gourich, K. Madani, C. H. Vial and A. Sekki, Desalination, 2011, 272(1-3), 246-253.

12 S. K. Nataraj, K. M. Hosamani and T. M. Aminabhavi, Water Res., 2006, 40(12), 2349-2356.

13 E. Rosales, M. Pazos and M. A. Sanromán, Desalination, 2011, 278(1-3), 312-317.

14 Y. Zhan, H. Li and Y. Chen, J. Hazard. Mater., 2010, 180(1-3), 481-485.

15 R. Wang, J. Guo, D. Chen, Y. E. Miao, J. Pan, W. W. Tjiu and T. Liu, J. Mater. Chem., 2011, 21, 19375-19380.

16 P. F. Du, L. X. Song, J. Xiong, Z. Q. Xi, J. J. Chen, L. H. Gao and N. Y. Wang, Nanosci. Nanotechnol., 2011, 11(9), 7723-7728.

17 A. K. Avinash, N. K. Ashwini, S. L. Harshad and S. P. Govindwar, Int. Biodeterior. Biodegrad., 2014, 86, 364371.

18 X. Meng, G. Liu, J. Zhou and Q. S. Fua, Bioresour. Technol., 2014, 151, 63-68.

19 P. Saha, S. Chowdhury, S. Gupta and I. Kumar, Chem. Eng. J., 2010, 165, 874-882.

20 X. S. Wang, Y. Zhou, Y. Jiang and C. Sun, J. Hazard. Mater., 2008, 157, 374-385.

21 A. Malik, Environ. Int., 2004, 30, 261-278.

22 N. S. Maurya, A. K. Mittal, P. Cornel and E. Rother, Bioresour. Technol., 2006, 97, 512-521.

23 A. Saeed, M. Iqbal and S. I. Zafar, J. Hazard. Mater., 2009, 168, 406-415.

24 K. Vijayaraghavan, S. W. Won, J. Mao and Y. S. Yun, Chem. Eng. J., 2008, 145, 1-6.

25 V. J. P. Vilar, C. M. S. Botelho and R. A. R. Boaventura, J. Hazard. Mater., 2007, 147, 120-132.

26 X. Wang, X. Chen, K. Yoon, D. Fang, B. S. Hsiao and B. Chu, Environ. Sci. Technol., 2005, 39, 7684-7691.

27 N. Zaghbani, A. Hafiane and M. Dhahbi, Sep. Purif. Technol., 2007, 55, 117-124.

28 J. H. Wendorff, S. Agarwal and A. Greiner, Electrospinning: Materials, Processing, and Applications, Wiley-VCH Verlag GmbH \& Co. KGaA, 2012.

29 F. Kayaci, Z. Aytac and T. Uyar, J. Hazard. Mater., 2013, 261, 286-294.

30 J. Wang, K. Pan, E. P. Giannelis and B. Cao, RSC Adv., 2013, 3, 8978-8987.

31 N. Mahanta and S. Valiyaveettil, RSC Adv., 2013, 3, 27762783.

32 R. Balamurugan, S. Sundarrajan and S. Ramakrishna, Membranes, 2011, 1, 232-248.

33 E. Eroglu, V. Agarwal, M. Bradshaw, X. Chen, S. M. Smith, C. L. Raston and K. Y. Iyer, Green Chem., 2012, 14, 26822685.
34 M. Gensheimer, A. Brandis-Heep, S. Agarwal, R. K. Thauer and A. Greiner, Macromol. Biosci., 2011, 11, 333-337.

35 S. Klein, J. Kuhn, R. Avrahami, S. Tarre, M. Beliavski, M. Green and E. Zussman, Biomacromolecules, 2009, 10, 1751-1756.

36 S. Klein, R. Avrahami, E. Zussman, M. Beliavski, S. Tarre and M. Green, J. Ind. Microbiol., 2012, 39, 1605-1613.

37 W. Salalha, J. Kuhn, Y. Dror and E. Zussman, Nanotechnology, 2006, 17, 4675-4681.

38 O. F. Sarioglu, O. Yasa, A. Celebioglu, T. Uyar and T. Tekinay, Green Chem., 2013, 15, 2566-2572.

39 A. Vajdai, B. Szabó, K. Süveqh, R. Zelkó and G. Ujhely, Int. J. Pharm., 2012, 429, 135-137.

40 C. C. Hsueh, B. Y. Chen and C. Y. Yen, J. Hazard. Mater., 2009, 167, 995-1001.

41 I. M. Banat, P. Nigam, D. Singh and R. Marchant, Bioresour. Technol., 1996, 58, 217-227.

42 A. Pandey, P. Singh and P. L. Iyengar, Int. Biodeterior. Biodegrad., 2007, 59, 73-84.

43 A. Celebioglu and T. Uyar, Mater. Lett., 2011, 65, 2291-2294. 44 Ø. Ørmen, M. Q. Regue, J. M. Tomas and P. E. Granum, Microb. Pathog., 2003, 35, 189-196.

45 S. E. Brown, A. A. Reilley, D. L. Knudson and C. A. Ishimaru, Curr. Microbiol., 2002, 44, 112-119.

46 K. H. Gartemann, O. Kirchner, J. Engemann, I. Gräfen, R. Eichenlaub and A. Burger, J. Biotechnol., 2003, 106, 179191.

47 B. H. Iglewski, et al., Pseudomonas, in Baron's Medical Microbiology, ed. S. Baron, University of Texas Medical Branch, ISBN 0-9631172-1-1, 4th edn. 2003.

48 A. Pandey, P. Singh and L. Iyengar, Int. Biodeterior. Biodegrad., 2007, 59, 73-84.

49 C. Tsioptsias, K. G. Sakellariou, I. Tsivintzelis, L. Papadopoulou and C. Panayiotou, Carbohydr. Polym., 2010, 81(4), 925-930.

50 J. W. Costerton, Z. Lewandowski, D. E. Caldwell, D. R. Korber and H. M. Lappin-Scott, Annu. Rev. Microbiol., 1995, 49, 711745.

51 M. Matsukawa and E. P. Greenberg, J. Bacteriol., 2004, 186, 4449-4456.

52 N. O. San, H. Nazır and G. Dönmez, Corros. Sci., 2011, 53, 2216-2221.

53 N. O. San, H. Nazır and G. Dönmez, Corros. Sci., 2012, 65, 113-118.

54 K. C. Chen, J. Y. Wu, D. J. Liou and S. C. J. Hwang, J. Biotechnol., 2003, 101, 57-68.

55 A. Srinivasan and T. Viraraghavan, J. Environ. Manage., 2010, 91, 1915-1929.

56 A. Arunarani, P. Chandran, B. V. Ranganathan, N. S. Vasanthi and S. Sudheer Khan, Colloids Surf., 2013, 102, 379-384.

57 J. P. Chen and Y. S. Lin, Process Biochem., 2007, 42(6), 934942.

58 A. A. Kadam, A. A. Telke, S. S. Jagtap and S. P. Govindwar, J. Hazard. Mater., 2011, 189, 486-494. 